\title{
PENGEMBANGAN MODUL MATA KULIAH ELEKTRONIKA DASAR II MATERI ROBOTIKA UNTUK MENINGKATKAN KEMANDIRIAN DAN PENGETAHUAN
}

Nehru ${ }^{1}$, Ahmad Aldi $^{2}$, dan Fibrika Rahmat Basuki ${ }^{3}$

Prodi Pendidikan Fisika Universitas Jambi, Jambi, Indonesia

Email: ahmadaldi241996@gmail.com

\section{Info Artikel}

Diterima: 26 November 2018

Disetujui: 21 April 2019

Dipublikasikan: 15 Desember 2019

\begin{abstract}
Abstrak:
Penelitian ini bertujuan untuk mendesain Modul Elektronika Dasar II pada materi robotika dan mengetahui persepsi mahasiswa. Penelitian ini merupakan penelitian dan pengembangan yang menggunakan model ADDIE. Subjek penelitian ini yaitu ahli materi, ahli media serta 21 mahasiswa. Instrument yang digunakan adalah lembar wawancara, lembar validasi serta lembar angket persepsi. Teknik analisis data kualitatif dilakukan secara deskriptif dan data kuantitatif dianalisis menggunakan statistik deskriftif. Hasil penelitian ini berupa modul cetak yang berisi materi tentang dasar robotika, piranti pengendali, mikrokontroler dan aktuator. Modul dilengkapi dengan kegiatan belajar mandiri merancang projek sederhana. Hasil validasi ahli materi diperoleh skor 84 dengan kategori baik dan hasil validasi ahli media diperoleh skor 109 dengan kategori sangat baik. Hasil persepsi mahasiswa terhadap modul diperoleh skor 1280 dengan kategori baik.
\end{abstract}

Kata kunci: Modul elektronika dasar II, mandiri, pengetahuan.

\begin{abstract}
:
This research aims to design basic electronics module II on robotics material and to know student perception. This research was research and development that uses the ADDIE model. The subject of this study was material experts, media experts, and 21 students. The instruments used were interview sheets, validation sheets, and questioner. Qualitative data analysis techniques are done descriptively and quantitative data is analyzed using descriptive statistics. The result was a printed module containing material about the basic robotics, controlling device, microcontroller, and an actuator. Modules were equipped with self-learning activities designing simple projects. Material expert validation results obtained a score of 84 with good categories and the validation result of media experts acquired score 109 with excellent categories. The student perception result of the module obtained a score of 1280 with good categories.
\end{abstract}

Keywords: Basic electronic module II, independent, knowledge. 


\section{Pendahuluan}

Robotika adalah ilmu yang mempelajari mengenai proses perancangan dan pengembangan robot serta membahas mengenai penerapan- penerapan teknologi robotika pada kehidupan manusia. Dalam penerapannya, ilmu robotika erat hubungannya dengan ilmu kecerdasan buatan. Teknologi dan aplikasi robot terus berkembang secara cepat, baik dari sisi kehandalan, jangkauan kemampuan dan bidangnya maupun harganya (Nehmzow, 2000).

Robotika memiliki unsur yang sedikit berbeda dengan ilmu-ilmu dasar atau terapan yang lain dalam berkembang. Ilmu dasar biasanya berkembang dari suatu hipotesis yang kemudian diteliti secara metodis. Ilmu terapan dikembangkan setelah ilmu-ilmu yang mendasarinya berkembang dengan baik. Sedangkan ilmu robotika lebih sering berkembang melalui pendekatan secara praktis pada awalnya. Kemudian melalui suatu pendekatan atau perumpamaan dari hasil pengamatan perilaku mahluk hidup atau benda/mesin/peralatan bergerak lainnya dikembangkanlah penelitian secara teoritis. Dari teori kembali kepada praktis, dan dari robot berkembang menjadi lebih canggih. (Supriyanto, dkk: 2010).

Robot secara garis besar disusun oleh 3 komponen utama, yaitu sensor, actuator, dan mikrokontroler. Actuator adalah komponen yang digunakan untuk menggerakkan robot. Pergerakan ini bisa bersifat stasioner, seperti pergerakan sendi pada robot berbentuk tangan atau pergerakan yang bersifat mobile, seperti pergerakan sebuah robot beroda dari satu tempat ke tempat lainnya. Sensor adalah komponen yang digunakan untuk mendapatkan masukan dari lingkungan tempat robot itu berada. Analogi sensor pada makhluk hidup adalah indra yang digunakan untuk merasakan lingkungan sekitar. Tipe masukan yang bisa diterima bergantung pada kemampuan sensor tersebut untuk menerima tipe masukan yang diinginkan.

Perkembangan robotika dunia saat ini sedang pesat-pesatnya bahkan sekarang manusia bisa menciptakan robot yang sangat mirip dengan manusia itu sendiri atau biasa disebut robot humanoid. Saat ini, robot yang paling maju mampu berpikir, bertindak dan berinteraksi layaknya manusia. Perkembangan teknologi ini sangat menakjubkan dengan populasi yang terus beranjak naik di banyak negara, terutama untuk menunjang sektor industri.

Daniel Claes dan Karl Tuyls membuat robot yang mampu menghindari tabrakan dalam ruangan kerja Bersama yang membuat kecelakaan kerja pada manusia bisa diminilisir yang dipublikasikan dalam jurnal yang berjudul "Multi robot collision avoidance in a shared workspace".

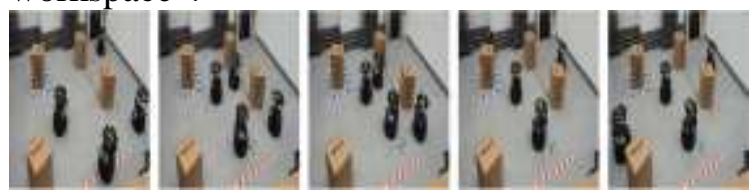

Gambar 1. Simulasi Robot Menghindari Tabrakan.

Selain dalam bidang indsutri dalam bidang militer juga dikembangkan seperti yang dioublikasikan Changsu $\mathrm{Ha}$ et al mampu mebuat pleton robot yang bergerak Bersama secara otomatis yang dapat memprediksi jalur yang dipublikasikan dalam artikel berjudul "Teleoperation of a platoon of distributed wheeled mobile robots with predictive display" dan masi bayak lagi. Robot ini bisa dimanfaatkan untuk infantry tank di masa depan.

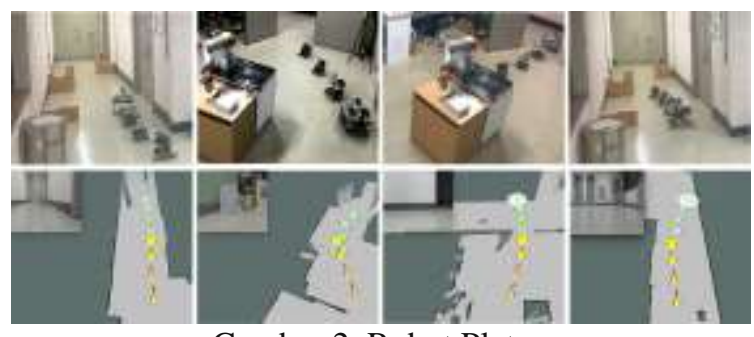

Gambar 2. Robot Pleton

Selain digunakan untuk keperluan industri dan militer, robot difungsikan secara luas di bidang lainnya. Untuk bidang konstruksi, misalnya, dunia mengenal ERO Robot yang digunakan untuk merontokkan bangunan dan mendaur ulang betonnya. Robot yang dirancang oleh Omer Haciomeroglu ini sangat membantu mengurangi "limbah" dan menjawab tantangan penghematan enggunaan sumberdaya alam dalam sebuah proyek konstruksi. Seperti ERO adalah robot dekonstruksi beton yang dirancang untuk membongkar struktur beton bertulang yang memungkinkan bahan bangunan itu digunakan kembali untuk bangunan beton pra-pabrikasi baru, 
Di dunia penerbangan, dikenal pesawat tanpa awak yang digunakan untuk berbagai keperluan. Autonomous System Technology Related Airborne Evaluation and Assesment (ASTRAEA), sebuah lembaga pengkajian teknologi penerbangan di Inggris, telah berhasil merancang dan menguji sebuah pesawat penumpang yang terbang tanpa awak (pilot) ketika mengudara. Pilot di dalam pesawat yang disebut sebagai "The Flying Test Bed" ini hanya melepaslandaskan dan mendaratkan pesawat. Sisanya, perjalanan sepanjang $500 \mathrm{mil}$ dilakukan oleh pilot di darat yang dipandu oleh National Air Traffic Services (NATS), pengatur lalu lintas penerbangan di Inggris.

Selanjutnya Mind uploading atau pengunggahan pikiran adalah teknologi yang terpenting untuk mendukung keabadian digital seperti yang diungkapkan oleh Ryan Kurzweil, seorang insinyur di Google, pada sebuah konferensi tentang masa depan yang diadakan di Amerika Serikat. Gagasan ini didukung oleh seorang ilmuwan terkenal, Stephen Hawking, yang menyatakan bahwa otak mampu berdiri sendiri di luar tubuh dan mendukung manusia untuk memeroleh "keabadian" ini dan masih banyak lagi.

Salah satu bidang yang mendukung pesatnya penelitian di bidang teknologi adalah perkembangan arsitektur pengendali robot (robot control architecture). Arsitektur pengendali robot membentuk tulang punggung dari sistem robot yang kompleks dan sempurna (Coste dkk, 2000). Arsitektur pengendali menyediakan beberapa prinsipprinsip untuk mengorganisasikan sistem pengendali pada robot yang menjelaskan bagaimana sistem robot tersebut dibagi menjadi beberapa sub-sub sistem, dan menjelaskan sub-sub sistem tersebut berinteraksi serta menggambarkan konsep algoritma dan komputasi yang digunakan sistem tersebut secara keseluruhan. Beberapa arsitektur pengendali robot telah dikembangkan, antara lain arsitektur pertimbangan (deliberative control architecture), arsitektur reaktif (reactive control architecture), arsitektur hibridisasi (hybrid control architecture) dan arsitektur berbasis perilaku (behavior-based control architecture) (Arkin, 1998) (Mataric, 1997) (Mataric, 1998).

Di Indonesia pengembangan robot terbentur pada masalah klasik yaitu dana, yang Pengembangan Modul Mata Kuliah .... (Nehru, dkk) hal:1-16 menyebabkan perkembangan robot di Indonesia belum semaju seperti negara-negara di Asia lainnya, seperti Jepang, Korea Selatan, dan China. Namun, ini juga harus dimaklumi karena perkembangan teknologi ini baru dimualai sekitar satu dekade lalu yang ditandai dengan banyaknya pelajar dan mahasiswa Indonesia yang mendulang prestasi di ajang kompetisi robot internasional.

Saat ini perkembangan ilmu robotika telah merata seluruh tanah air yang dibuktikan dengan keikutsertaan mahasiswa hampir seluruh kepulauan yang ada di Indonesia. Prestasi mahasiswa Indonesia untuk bidang robot juga sudah diperhitungkan di dunia, terbukti dengan beberapa kali dapat menjuarai perlombaan-perlombaan tingkat dunia.

Di Indonesia sejak tahun 1980-an, kebijakan nasional dalam pengembangan riset dan teknologi telah memberikan dukungan pada litbang permesinan otomatis dalam rangka menunjang sumber daya manusia Indonesia yang memiliki minat dan kemampuan untuk belajar dan menguasai teknologi robotika. Sehingga dibangunlah laboratoriumlaboratorium, seperti MEPPO (Mesin Perkakas Teknik Produksi dan Otomatis). Sejak boratorium tersebut beraneka macam mesin otomatis dan robot berhasil dikembangkan dan dikomersilkan oleh berbagai industri. Saat ini Indonesia telah berhasil menciptakan robot yang mampu mengontrol seluruh sistem operasi suatu pabrik. Selain itu ilmu robotika telah merambah ke arah pendidikan, hal ini dibuktikan dengan kontes robot pertama kali yang diadakan oleh Depdiknas pada tahun 1990. Indonesia pun telah mengirimkan perwakilan pada kontes Asia Pasific Broadcasting (ABU) Robocon yang diselenggarakan di Tokyo dan berhasil pulang menjadi juara.

Perkembangan robot pun menjadi tidak teratur. Banyak pecinta robot mengembangkan robot, terus melakukannya tanpa dukungan apapun dari pemerintah. Di lingkungan militer, teknologi robot tetap dikembangkan. Lembaga Pengkajian Teknologi (Lemjitek) TNI AD yang ada di Karangploso, Malang, Jawa Timur, pada 2009 lalu telah mampu menciptakan robot tempur dengan sistem kendali jarak jauh yang memanfaatkan gelombang radio.

Pakar Robotika dari Universitas Indonesia, Dr. Ir. Wahidin Wahab, M.Sc., kini 
tengah mengembangkan robot pematung yang akan mampu membantu tugas para pematung. Atau bisa dibilang meringankan pekerjaan para pematung.

Namun tidak semua mahasiswa yang mempelajari robotika mengerti dan memahami akan materi robotika. Seperti di Universitas Jambi Khususnya prodi Pendidikan Fisika pada mata kuliah elektronika dasar II. Pada mata kuliah elektronika dasar II terdaoat materi yang mempelajari robotika. Robotika didalam elektronika dasar II merupakan hal yang masih baru bahkan baru dimulai 2-3 tahun ini. Sehingga mahahsiswa masih sangat awam dengan teknologi robot. Bahan ajar yang dimiliki juga masi terbatas, Bahkan beberapa mahahasiswa membeli robot untuk dipelajari secara otodidak dikarenakan kurangnya sumber belajar yang bisa dipelajari.

Untuk meningkatkan pemahaman mahasiswa dalam mempelajari robotika maka perlu adanya pengembangan bahan ajar agar mahasiswa dapat mempelajari robotika secara lebih mudah. Modul pembelajaran robotika dipilih sebagai bahan ajar dikarenkan sifat dari modul yang bisa dipelajari secara otodidak dan dapat meningkatkan pengetahuan serta pemahaman mahasiswa tentang robtika. Modul pembelajaran harus mampu mengajak mahasiswa untuk aktif dalam memahami proses pemanfaatan robot. Kesempatan belajar mahasiswa dalam memahami setiap bagian robot harus diberikan.

Modul yang dibuat diisi dengan materi materi yang berkaitan dengan robotika, serta dilengkapi dengan latihan soal dan juga beberapa contoh program yang bias dipraktekan langsung oleh mahasiswa, dan juga modul ini dilengkapai dengan cd yang berisi software, software yang akan digunakan untuk berlajar mandiri seperti CodeVision AVR untuk belajar menulis program dan Proteus 8 untuk mensimulasikan. Penelitian ini bertujuan untuk mengembangkan modul yang dapat digunakan secara mandiri oleh mahasiswa dalam mempelajari materi robotika.

\section{Metode Penelitian}

Jenis Penelitian

Jenis penelitian ini adalah penelitian dan pengembangan (research and development). Adapun model pengembangan dalam penelitian ini menggunakan model
ADDIE dengan tahapan nalyze, design, develop, implement dan evaluate (Branch, 2009). Tetapi penelitian ini tidak melakukan tahap Implement.

Waktu dan Tempat Penelitian

Penelitian dilakukan pada $04 \mathrm{~s} / \mathrm{d} 05$ juli 2018 pukul 10.00 wib di ruangan F7 Program Studi Pendidikan Fisika.

\section{Target/Subjek Penelitian}

Subjek ujicoba dalam penelitian ini adalah 2 orang validator yaitu ahli materi dan ahli media serta mahasiswa Pendidikan Fisika FKIP Universitas Jambi Angkatan 2015 sebanyak 21 orang mahasiswa yang telah mengontrak mata kuliah Elektronika Dasar 2.

Prosedur

Prosedur pengembangan penelitian ini adalah sebagai berikut:

1. Analyze (Analisisis)

Kegiatan analisis dalam penelitian ini secara lebih rinci dijabarkan sebagai berikut.

a. Validasi Kesenjangan Kerja

Tujuan dari prosedur ini adalah menghasilkan sebuah pernyataan tujuan dasar untuk menempatkan kesenjangan pelaksanaan dan mencari solusi dari kesenjangan tersebut. Bisa dilakukan observasi ataupun wawancara.

b. Menentukan Tujuan Instruksional

Tujuan dari prosedur ini adalah untuk menghasilkan tujuan sesuatu yang merespon kesenjangan pelaksanaan yang disebabkan oleh kurangnya pengetahuan dan keterampilan. Tujuan instruksional ini bisa ditentukan setelah mengidentifikasi kesenjangan antara kondisi nyata. Setelah diperoleh tujuan instruksional, dilanjutkan dengan memilih atau menetapkan prioritas tindakan yang akan dilakukan. Dalam hal ini, peneliti menetapkan prioritas tindakannya dengan melakukan pengembangan bahan ajar berupa modul cetak.

c. Analis Karakteristik Mahasiswa

Bertujuan untuk mengidentifikasi kemampuan, pengalaman, prefensi, dan motivasi dari mahasiswa (dilakukan dengan teknik penyebaran angket)

d. Memerikasa Sumber Daya yang Ada

Bertujuan untuk mengidentifikasi halhal yang dapat mendukung keberhasilan 
untuk semua proses ADDIE (dilakukan dengan teknik dokumentasi).

e. Menyusun Rencana Manajemen Projek

Tujuanya adalah untuk membuat jadwal dan harapan peneliti dalam melakukan setiap proses ADDIE.

2. Design (Perancangan)

Adapun tahap-tahapannya sebagai berikut:

$a$. Menentukan Task Inventory

Tujuan dari prosedur ini adalah untuk mengidentifikasi komponen materi yang penting dikuasai dalam mencapai tujuan instruksional. Tujuan kerja dapat dianalisis sesuai dengan pengetahuan, keterampilan,

$b$. Menyusun performance objective

Tujuan dari prosedur ini adalah untuk membuat tujuan yang di dalamnya mencakup komponen kondisi, komponen kinerja dan komponen kriteria. Ada tiga komponen dari tujuan yaitu: kinerja apa yang akan dilakukan, kondisi penting dimana kinerja diharapkan terjadi dan kriteria kualitas atau standar kinerja yang dianggap dapat diterima.

c. Menghasilkan testing strategies

Pada langkah ini peneliti menyusun item test untuk menilai ketercapaian siswa dalam pembelajaran yang telah dilakukan. Penyusunan item tes disesuaikan dengan task inventory dan Performance objective yang telah ditentukan sebelumnya pada setiap kegiatan pembelajaran.

$d$. Menghitung Estimasi Biaya

Pada langkah ini peneliti menghitung biaya yang dikeluarkan baik pada semua tahap ADDIE juga biaya pembuatan produk.

3. Develop (pengembangan)

Adapun tahap-tahapannya sebagai berikut:

a. Menghasilkan Konten/isi

Tujuan dari prosedur ini adalah untuk menghasilkan rencana pembelajaran. Konten/isi adalah titik fokus untuk melibatkan siswa selama proses konstruksi pengetahuan.

b. Mengembangkan Panduan Belajar Siswa

Pada tahap ini peneliti mengembangkan modul Elektronika Dasar 2. Modul yang dikembangkan berupa modul cetak. Tujuannya adalah untuk memberikan info.

c. Melakukan Revisi Formatif

Peninjauan dilakukan oleh validator ahli materi dan validator ahli media.
Dalam hal ini peneliti tidak melakukan uji coba secara utuh. Peneliti hanya menunjukkan produk dalam waktu singkat, kemudian mengambil data presepsi mahasiswa melalui angket yang disebarkan.

4. Evaluate (evaluasi)

Adapun tahap-tahapannya sebagai berikut:

a. Menentukan Kriteria Evaluasi

Mengidentifikasi

persepsi, pembelajaran, dan kinerja sebagai tiga tingkat utama evaluasi terkait dengan desain instruksional.

b. Memilih Alat Evaluasi

Mengidentifkasi atribut utama untuk masing-masing alat evaluasi untuk desain instruksional yang dipilih dalam pendekatan ADDIE.

c. Melakukan Evaluasi

Memberikan pedoman untuk melakukan evaluasi desain instruksional, dalam penelitian ini adalah evaluasi terhadap modul ajar yang telah dibuat dan setiap tahap ADDIE.

\section{Instrumen Penelitian}

Penelitian ini menggunakan metode penelitian pengembangan. Maka data penelitian yang digunakan adalah data kualitatif dan kuantitatif. Berdasarkan jenis data di atas maka instrument yang digunakan adalah:

1. Dokumentasi

Data dokumentasi yang digunakan adalah:
a. Telaah dokemen berupa buku-buku robotika
b. Kelengkapan dokumen berupa foto.

2. Lembar Wawancara

Yang digunakan adalah lembar wawancara terbuka terkait modul robotika elektronika dasar 2.

\section{Tabel 1. Tabel Kisi-Kisi Wawancara}

Kisi-Kisi Pertanyaan Wawancara
a. Materi robotika
b. Tanggapan mahasiswa tentang materi robotika.
c. Kesulitan yang dialami
d. Kendala apa saja yang diteumi
e. Solusi yang diinginkan 
3. Lembar validasi

Tabel 2. Kisi-Kisi Lembar Validasi Ahli Materi

\begin{tabular}{|c|c|}
\hline Aspek & Indikator \\
\hline $\begin{array}{l}\text { Kelayakan } \\
\text { isi }\end{array}$ & $\begin{array}{l}\text { 1. Kesesuaian materi dengan SK } \\
\text { dan KD } \\
\text { 2. Keakuratan Materi } \\
\text { 3. Pendukung materi pembelajaran } \\
\text { 1. Lugas } \\
\text { 2. Komunikatif } \\
\text { 3. Dialogis dan Interaktif } \\
\text { 4. Kesesuaian dengan tingkat } \\
\text { perkembangan mahasiswa } \\
\text { 5. Keruntutan dan keterpaduan } \\
\text { alur pikir } \\
\text { 6. Penggunaan Istilah, simbol atau } \\
\text { ikon }\end{array}$ \\
\hline \multicolumn{2}{|c|}{ Tabel 3. Kisi-kisi Lembar Validasi Ahli Media } \\
\hline Aspek & Indikator \\
\hline $\begin{array}{l}\text { Ukuran } \\
\text { Modul }\end{array}$ & 1. Ukuran Fisik Modul \\
\hline $\begin{array}{l}\text { Desain } \\
\text { Sampul } \\
\text { Modul }\end{array}$ & $\begin{array}{l}\text { 1. Tata Letak Sampul Modul } \\
\text { 2. Huruf yang digunakan menarik } \\
\text { dan mudah dibaca } \\
\text { 3. Ilustrasi sampul modul }\end{array}$ \\
\hline $\begin{array}{l}\text { Desain Isi } \\
\text { Modul }\end{array}$ & $\begin{array}{l}\text { 1. Konsistensi tata letak } \\
\text { 2. Unsur tata letak harmonis } \\
\text { 3. Unsur tata letak lengkap } \\
\text { 4. Tata letak mempercepat } \\
\text { pemahaman } \\
\text { 5. Tipografi isi buku sederhana } \\
\text { 6. Tipografi mudah dibaca } \\
\text { 7. Tipografi isi buku memudahkan } \\
\text { pemahaman } \\
\text { 8. Ilustrasi isi }\end{array}$ \\
\hline
\end{tabular}

4. Lembar Kuisioner

Lembar kuesioner (angket) untuk melihat tanggapan subjek ujicoba tentang kelayakan modul. Digunakan untuk mengukur persepsi mahasiswa, Angket yang akan dibuat menggunakan skala likert(4 skala). Dengan ksisi-ksisi:

Tabel 4. Kisi-kisi Angket Persepsi Siswa

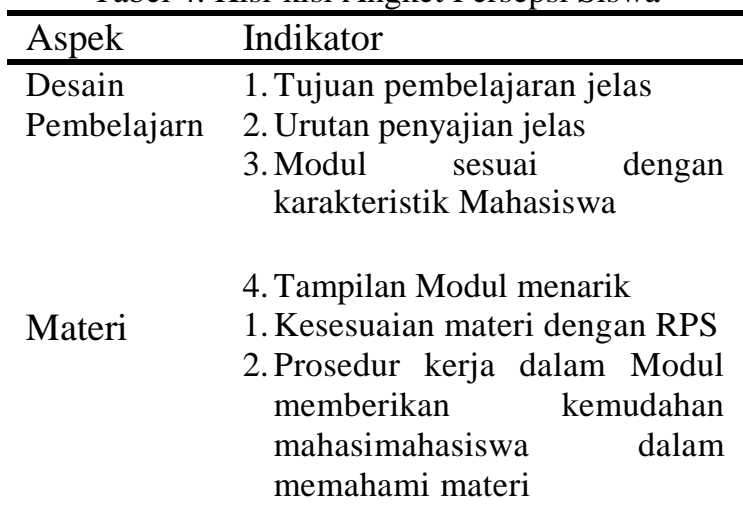

Pengembangan Modul Mata Kuliah .... (Nehru, dkk) hal:1-16
3. Penyajian materi didalam Modul sederhana dan mudah dipahami

Keterbacaan 1. Kalimat yang digunakan dalam modul

Modul mudah dipahami

2. Bahasa yang digunakan jelas dan sederhana

3. Tampilan judul dan subjudul jelas

4. Ukuran huruf pada tulisan sudah sesuai

5. Tampilan dan ukuran gambar sudah jelas

6. Informasi yang terdapat dalam Moduk jelas dan mudah dimengerti

Visualisasi 1.Langkah-langkah kegiatan Modul dalam Modul ini sangat membantu mahasiswa dalam membuat project

2. Modul mempermudah pemahaman siswa terhadap materi

3. Modul mendorong minat mahasiswa untuk belajar

4. Modul dapat membantu mahasiswa ingat terhadap materi pelajaran

5. Modul memberikan kemudahan kepada mahasiswa untuk mandiri

6. Modul membuat kegiatan pembelajaran menjadi menyenangkan

Teknik Analisis Insterumen

1. Uji Validitas angket mahasiswa

Sebuah instrumen valid apabila mampu mengukur objek yang diinginkan dan dapat mengungkapkan data dari variabel yang diteliti secara tepat. Valid berarti instrumen tersebut dapat digunakan untuk mengukur apa yang seharusnya diukur (Sugiyono, 2013). Perhitungan uji validitas menggunakan program komputer yaitu Microsoft Excell. Harga $r_{\text {hitung }}$ kemudian akan dikonsultasikan dengan $r_{\text {kritis }}=0,3$. Jika nila $r_{\text {hitung }}$ lebih besar atau sama dengan $r_{\text {kritis }}$ maka butir dari instrumen yang dimaksud adalah valid. Begitupun sebaliknya jika diketahui nilai $r_{\text {hitung }}$ lebih kecil dari $r_{\text {kritis }}$ maka instrumen tersebut tidak valid. Terdapat 18 soal valid dari 20 soal yang disediakan

2. Uji Reabilitas Angket Mahasiswa

Reliabilitas berkenaan dengan ketetapan suatu alat ukur atau ketetapan hasil 
pengukuran. Suatu instrumen memiliki tingkat reliabilitas yang memadai, apabila instrumen tersebut digunakan mengukur aspek yang diukur beberapa kali hasilnya sama. Sehingga, reliabilitas perlu untuk menyokong terbentuknya validitas. Dalam penelitian ini untuk mengukur reliabilitas ditentukan dengan rumus Alfa Cronbach sebagai berikut. Perhitungan uji reabilitas menggunakan program komputer yaitu IBM SPSS Statistic 25. Angket persepsi mahasiswa yang digunakan memiliki koefisien korelasi sebesar $\mathrm{r} 11=0,829$ dengan kategori sangat tinggi dimana menunjukan angket reliabel untuk digunakan. Koefisien reliabilitas tes berkisar antara 0,00-1,00 dengan perincian korelasi sebagai berikut:

Tabel 5. Kategori Reliabilitas

\begin{tabular}{ll}
\hline Besarnya nilai $r$ & Interpretasi \\
\hline $0,800-1,000$ & SangatTinggi \\
$0,600-0,799$ & Tinggi \\
$0,400-0,599$ & Cukup Tinggi \\
$0,200-0,399$ & Rendah \\
$0,000-0,199$ & Sangat rendah \\
\hline & (Sumber: Riduwan, 2013)
\end{tabular}

Analisis Data

1. Analisis Data Kualitatif

Analisis data kualitatif yang digunakan dalam penelitian ini berupa hasil angket kebutuhan, wawancara terhadap mahasiswa, serta lembar validasi ahli.

a. Analisis angket kebutuhan

Sebelum melakukan sebuah penelitian, dilakukan analisis kebutuhan mengidentifikasi masalah mendasar yang dibutuhkan dalam pengembangan modul. Analisis kebutuhan ini diawali dari pengalaman pembelajran Elektronika Dasar II dari peneliti yang mengalami kesulitan dalam melakukan pembelajaran. Hal yang dilakukan adalah dengan melakukan penyebaran angket kebutuhan pembuatan modul. Data yang diperoleh kemudian dikelompokan kedalam tabel-tabel data interval yang diurutkan berdasarkan nomor soal agar lebih mudah untuk diamati.. Dari data yang didapat dari analisis angket kebutuhan peneliti berkesimpulan bahwa dibutuhkanya bahan ajar tambahan dalam melaksanakan proses pembelajran elektronika dasar II materi robotika. b. Analisis wawancara

Setelah melakukan analisis angket kebutuhan awal peneliti memutuskan untuk melakukan wawancara terhadap mahasiswa yang telah mengontrak mata kuliah elektronika dasar II serta asisten dosen elektronika dasar II. Data yang diperoleh dari wawancara direkam menggunkan recorder Handphone kemudian hasil rekaman dirubah dalam bentuk teks dan diberi kode berdasarkan inisial dari nama narasumber. Yang kemudian diamati dimana didapat kesimpulan bahwa dibutuhkanya modul elektronika dasar II materi robotika

c. Analisi lembar validasi ahli

Setelah produk dikembangkan tahap selanjutnya adalah validasi ahli. Lembar validasi ahli yang telah diisi oleh validator kemudian dikelompokan berdasarkan table-tabel berdasarkan nomor indicator agar lebih mudah diamati. Setelah data didapat dan dikelmpokan maka dilakukan revisi formatif berdasarkan kolom saran dan hasil dari lembar validasi untuk selanjutnya di analisis apakah modul sudah layak digunakan atau masih harus melakukan revisi berikutnya.

2. Analisis Data Kuantitatif

Analisis data kuantitif yang disajikan secara statistic deskrifitif.

a. Penyajian Data

Mengkuantitatifkan hasil checking dengan memberi skor sesuai dengan bobot yang telah ditentukan sebelumnya.

Tabel 6. Skoring Skala Linkert.

\begin{tabular}{ll}
\hline Respons & Bobot Skor \\
\hline Sangat Setuju & 4 \\
Setuju & 3 \\
Tidak Setuju & 2 \\
Sangat $\quad$ Tidak & 1 \\
Setuju & \\
\hline
\end{tabular}

(Sumber: Sugiyono, 2015)

Dan kemudian data disajikan dalam bentuk tabel data nominal yang ditampilkan berupa yan berkaitan dengan pemusatan dan penyebaran data.

b. Ukuran Pemusatan Data

Ukuran pemusatan data yang dihitung adalah Mean, Median dan Modus yang 
dihitung dibantu menggunkan software Microsoft Excell.

c. Ukuran Penyebaran Data

Ukuran penyebaran data yang dihitung adalah Standar Deviasi, Varians data yang dibantu menggunkan software Microsoft Excell.

d. Kemudian setiap sub variabel dikategorikan menjadi empat kategori sebagai berikut :

Tabel 7. Range Persentase dan Kriteria Kualitatif

\begin{tabular}{ll}
\hline Rentang skor & Kriteria \\
\hline$X i+1,5 S D i \leq \bar{X} \leq X i+3,0 S D i$ & Sangat \\
& Baik \\
$X i+0 S D i \leq \bar{X}<X i+1,5 S D i$ & Baik \\
$X i-1,5 S D i \leq \bar{X}<X i+0 S D i$ & Cukup \\
& Baik \\
$X i-3 S D i \leq \bar{X}<X i-1,5 S D i$ & Kurang \\
& Baik \\
\hline
\end{tabular}

\section{Hasil Penelitian dan Pembahasan}

1. Analisis(Analyze) yiatu:

Pada thap ini dilakukan beberapa kegiatan

a. Validasi Kesenjangan Kerja

Untuk mendefinisikan kesenjangan yang terjadi, peneliti melakukan Untuk mengetahui pokok masalah pada bahan belajar tersebut, maka peneliti melakukan triangulasi pada hasil wawancara mahasiswa dan wawancara asisten dosen. Berdasarkan dari triangulasi kedua komponen tersebut, peneliti menemukan beberapa kesenjangan pada bahan ajar yang digunakan. Berikut dijelaskan secara rinci kesenjangan yang ditemukan peneliti.

\section{Sulitnya memahami materi}

Permasalahan yang ditemukan adalah tingkat pemahaman mahasiswa yang rendah dikarenakan kurangnya sumber belajar serta sumber belajar yang ada kebanyakan dalam bentuk file sehingga mahasiswa malas untuk mempelajarinya. Solusi yang dapat dilakukan adalah dengan mengadakan buku referensi utama dengan menggunakan bahasa yang dapat dipahami untuk mahasiswa Pendidikan Fisika UNJA.

\section{Kurang Menarik}

Permasalahan yang ditemukan adalah materi robotika kurang menarik, dikarenakan materi terlalu berat untuk dipahami, serta gambar-gambar yang ada kebanyakan masi dalam bentuk hitam puith, maka solusi yang ditawarkan adalah pembuatan modul dengan format yang lebih berwarna agar menarik minat mahasiswa dalam mempelajari materi robotika.

\section{Kurangnya panduan atau contoh}

permasalahan yang ditemukan adalah kurangnya contoh atau panduan pembuatan project yang diberikan dosen. Solusi yang ditawarkan peneliti adalah pembuatan modul yang memuat contoh-contoh project yang dapat membantu mahasiswa dalam melaksanakan project yang diberikan oleh dosen.

b. Menentukan Tujuan Instruksional

Setelah diketahui kesenjangan yang terjadi di lapangan, langkah selanjutnya adalah menentukan tujuan instruksional. Menurut Branch (2009) tujuan dari menentukan tujuan instruksional ini adalah untuk menghasilkan tujuan sesuatu yang merespon kesenjangan pelaksanaan yang disebabkan oleh kurangnya pengetahuan dan keterampilan. Tujuan instruksional ini bisa ditentukan setelah mengidentifikasi kesenjangan antara kondisi nyata. Berikut ini tujuan instruksional yang telah ditetapkan.

1. Pengenalan Robotika

- Memahami dasar-dasar robotika

- Memebdakan jenis-jenis robot berdasarkan tingkat teknologiMemahami system pembangun sebuah robot Mengetahui tahap-tahap pembuatan

2. Piranti Pengendali

- Memahami jenis piranti pengendali

- Memahami piranti pengendali tak terprogram

- Memahami piranti pengendali terprogram

3. Mikrokontroler

- Memahami dasar-dasar mikrokontroler

- Membedakan karakteristik mikrokontroler ATMEL Seri 8535 dan 16 
- Memahami dasar pemograman mikroktonroler

4. Aktuator Robot

- Memahami dasar-dasar penggerak motor satu arah dan dua arah

- Merancang Robot Line/Light Follower

c. Analisis Karakteristik Mahasiswa

Analisis karakteristik mahasiswa digunakan sebagai dasar dalam pengembangan bahan ajar yang akan dibuat. Analisis karakteristik mahasiswa dilakukan dengan menyebarkan angket kepada mahasiswa pendidikan fisika universitas jambi angkatan 2015. Berikut tabel penjelasan mengenai karakteristik mahasiswa:

1. Subjek Penelitian: mahasiswa Pendidikan Fisika Universitas Jambi Angkatan 2015 dengan jumlah 70 mahasiswa, dengan ratarata usia berkisar 20 tahun dengan rincian jenis kelamin adalah $90.0 \%$ perempuan dan $10.0 \%$ laki-laki, rata-rata berasal dari Provinsi Jambi dan hanya $14.6 \%$ dari luar Provinsi Jambi.

2. Menguasai bahasa Indonesia dan hanya $8.9 \%$ menguasai Bahasa Inggris.

d. Memeriksa Sumber Daya yang Tersedia Terdapat 3 sumber daya yang bisa di catat yaitu :

1. Konten: Di ruang F7 terdapat 1 buah banne yang berisi Visi Misi, 1 buah peringatan membuang sampah pada tempatnya, 1 buah proyektor, 1 buah kipas angin, 1 buah $\mathrm{AC}$ dan 1 buah TV uk. 40inch.Di ruang F10B terdapat 2 buah peringatan membuang sampah pada tempatnya, 1 buah pemberitahuan menghidupkan AC, 1 buah proyektor 1 buah kipas angin, 1 buah $\mathrm{AC}$ dan 1 buah TV uk. 40 inch. Di ruang G15 terdapat 1 buah banner yang berisi Visi Misi, 1 buah proyektor dan 3 buah kipas angina.

2. Teknologi: Terdapat ruang kelas sebanyak 3 ruangan: Ruang F7 (5 m x $6 \mathrm{~m}$ ) dengan kapasitas kursi 60 buah, 1 buah meja dan 1 buah kursi untuk dosen. Ruang F10B (3 m x $4 \mathrm{~m}$ ) dengan kapasitas kursi 38 buah, 1 buah meja dan 1 buah kursi untuk dosen. Ruang G15 (5 m x 7 m) dengan kapasitas kursi 45 buah, 1 buah meja dan 1 buah kursi untuk dosen. Terdapat ruang praktikum (5 $\mathrm{m} \quad \mathrm{x} \quad 6 \quad \mathrm{~m})$. Mampu menampung mahasiswa \pm 25 mahasiswa dalam sekali praktikum. Memiliki jumlah kursi sebanyak 38 buah dan 4 baris meja praktikum permanen yang mampu memuat \pm 6 mahasiswa di setiap barisnya. Terdapat 1 meja besar yang berfungsi sebagai meja demonstrasi. Terdapat ruang penyimpanan alat ( $3 \mathrm{~m} \mathrm{x} 3 \mathrm{~m}$ ) yang didalamnya terdapat 2 buah lemari penyimpanan alat dan 1 meja persiapan sebelum praktikum. Terdapat ruang petugas labor $(3 \mathrm{~m} \times 3 \mathrm{~m})$ yang didalamnya terdapat 1 meja petugas labor dan 4 buah kursi.

3. Manusia: Terdapat seorang petugas laboran, tamatan S1 Pendidikan Fisika Universitas Jambi. Pembimbing praktikum (asdos) yang terdiri dari mahasiswa yang sudah mengontrak mata kuliah yang akan dipraktikumkan dan minimal mendapat nilai B pada mata kuliah tersebut. Syarat lain yaitu memiliki nilai IPK $\geq 3,00$.

e. Menyusun Rencana Projek

Menyusun rencana projek adalah tahap terakhir dari tahap analisi. Tujuan dari menyusun rencana projek adalah untuk menentukan rencana kerja yang akan dilakukan, renacan tersebut menegaskan gambaran dari projek yang akan dilakukan. Berikut adalah rencana projek pembuatan produk modul elektronika dasar 2 materi robotika:

1. Perumusan tujuan pembelajaran berdasarkan RPS Elektronika Dasar II.

2. Mengumpulkan materi-materi robotika yang akan digunakan sebagai referensi pembuatan modul.

3. Memvalidasi materi dengan dosen pengampu Elektronika Dasar II.

4. Membuat desain modul.

5. Mengembangkan modul dengan menyusun materi robotika menyesuaikan dengan RPS yang ada menggunakan software microsoft word 2016 yang akan dicetak menjadi modul materi robotika.

6. Melakukan validasi modul yang terdiri dari validasi media dan validasi materi.

7. Melakukan perbaikan modul sesuai hasil dari validasi yang dilakukan

8. Mengambil data persepsi mahasiswa terhadap modul yang telah dikembangkan.

9. Menganilisi data persepsi mahasiswa yang telah diperoleh. 


\section{Perancangan(Design $)$}

Pada tahap ini adapun langkah yang ditempuh iyalah:

a. Menetukan Task Inventory

Penentuan task inventory dilakukan dengan maksud untuk mengidentifikasi komponen materi yang penting dikuasai dalam mencapai tujuan instruksional.

\section{b. Menyusun Performance Objective}

Tujuan dari prosedur ini adalah untuk membuat tujuan yang didalamnya mencakup komponen kondisi, komponen kinerja dan komponen kriteria. Ada tiga komponen dari tujuan yaitu: kinerja apa yang akan dilakukan, kondisi penting dimana kinerja diharapkan terjadi dan kriteria kualitas atau standar kinerja yang dianggap dapat diterima.

\section{c. Menyusun Testing Strategies}

Pada tahap ini peneliti menyusun item test untuk menilai ketercapaian siswa dalam pembelajaran yang telah dilakukan. Menurut Barnch (2009) penyusunan item tes disesuaikan dengan tujuan pembelajaran, task inventory dan Performance objective yang telah ditentukan sebelumnya pada setiap kegiatan pembelajaran.

d. Menghitung Estimasi Biaya

Pada langkah ini peneliti memperkirakan biaya yang dikeluarkan. Menurut (Branch, 2009) hal ini perlu dilakukan untuk meyakinkan peneliti apakah semua proses dapat dilakukan dengan kemampuan dana yang dimiliki. Yaitu sebesar Rp. 430.000.

\section{Pengembangan (Development)}

Tujuan dari tahap ini adalah untuk memvalidasi sumber belajar yang telah ditentukan pada tahap desain. Hasil dari tahap ini adalah modul elektronika dasar 2 secara menyeluruh. Dalam (Branch, 2009) prosedur yang dilakukan pada tahap ini meliputi:

a. Menghasilkan Konten

Menurut (Branch, 2009) menghasilkan konten yang dimaksud adalah menyusun rencana pembelajaran. Rencana yang dibuat harus syarat akan strategi yang baik karena dalam proses pembelajaran ini mahasiswa akan membangun pengetahuannya.

b. Mengembangkan pedoman belajar siswa
Pada prosedur ini peneliti mengembangkan modul materi robotika pada mata kuliah elektronika dasar 2 pendidikan fisika Universitas Jambi. Modul yang dikembangkan merupakan modul cetak. Muatan yang ada di dalam modul berdasar pada hasil yang diperoleh dari tahap analyze dan design. Materi dimulai dari pengenalan struktur robotika. Adapun langkah-langkah yang dilakukan penliti pada prosedur ini adalah sebagai berikut:

1. Membuat/mendesain cover

Membuat cover yang sesuai dengan isi materi yang akan disampaikan. pada langkah ini peneliti membuat desain cover menggunakan aplikasi Adobe photoshop cc 2018. Desain cover dapat dilihat pada gambar 4.1 dibawah ini:

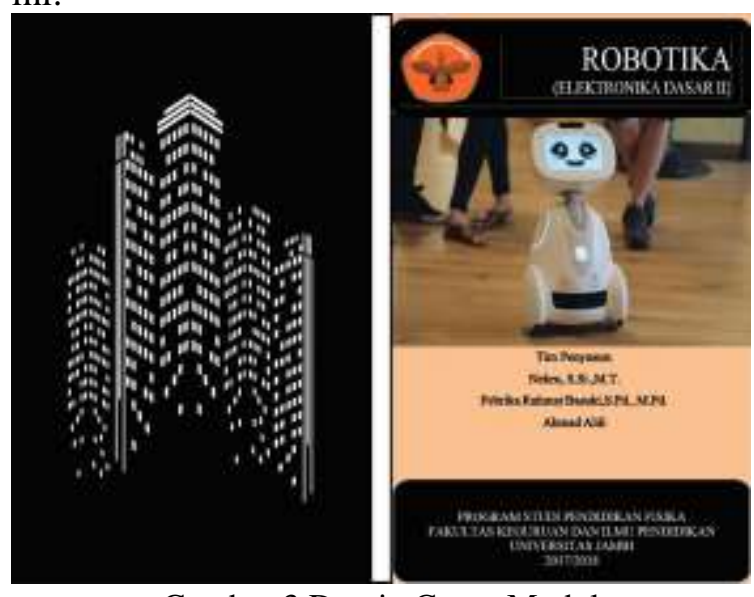

Gambar.3 Desain Cover Modul

2. Membuat petunjuk pemakain modul

Membuat petunjuk pemakaian modul. Hal ini dicantumkan agar mahasiswa mengerti bagaimana cara menggunakan modul untuk mencapai tujuan pembelajaran yang diharapkan. Berikut petunjuk pemakaian modul yang dikembangkan oleh peneliti:

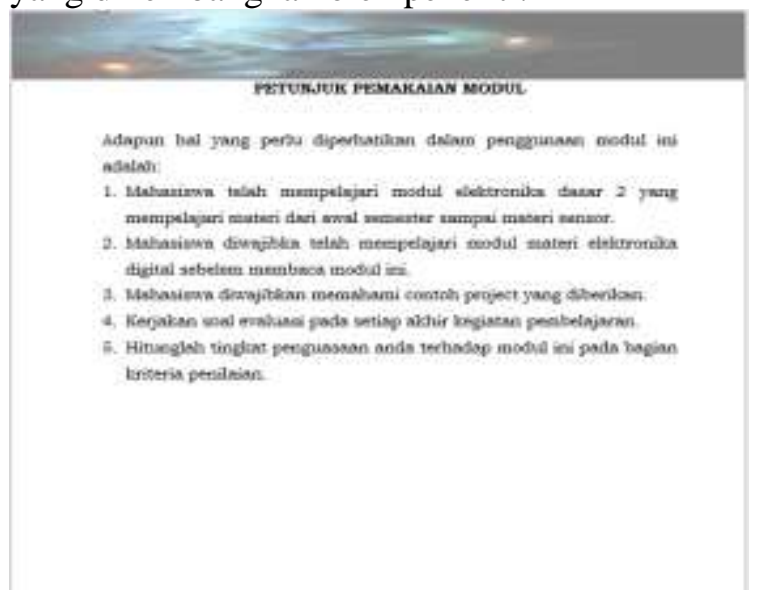

Gambar 4. Gambar Petunjuk Penggunaan Modul 
3. Membuat Kriteria Penilaian Diri

Penilaian diri yang ada pada modul ini, diadopsi dari modul yang telah ada sebelumnya yaitu Modul Elektronika Dasar 1 buatan Rilo Natanael Sibarani (2017). Penilaian diri pada modul ini berdasarkan pada soal evaluasi yang ada pada setiap kegiatan pembelajaran dengan melakukan perhitungan matematis pada soal yang dikerjakan sehingga hal tersebut dapat berguna bagi mahasiswa dalam menilai dirinya sendiri apakah telah berhasil menyelesaikan kegiatan pembelajaran pada modul ini. Adapun kriteria penilaian dapat dilihat pada gambar di bawah ini:

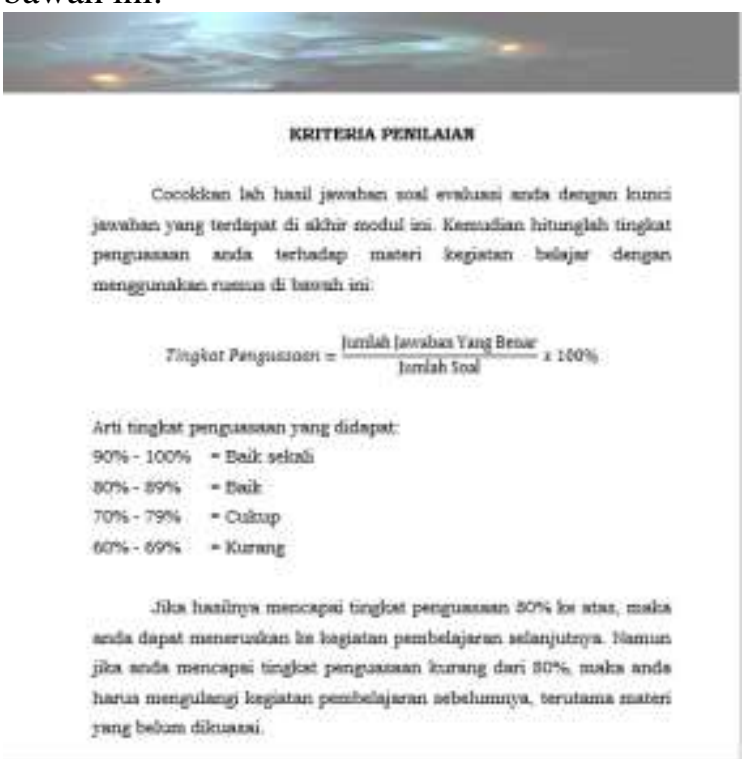

Gambar 5. Gambar Kriteria Penilaian

4. Membuat Pendahuluan Bab Serta Tujuan Pembelajarn

Tujuan pembelajaran pada modul ini disesuaikan dengan RPS pada mata kuliah Elektronika Dasar 2. Hal ini tentu sangat perlu dicantumkan agar mahasiswa mengetahui tujuan dari materi yang akan dipelajari. Adapun tujuan pembelajaran dapat dilihat pada gambar di bawah ini:

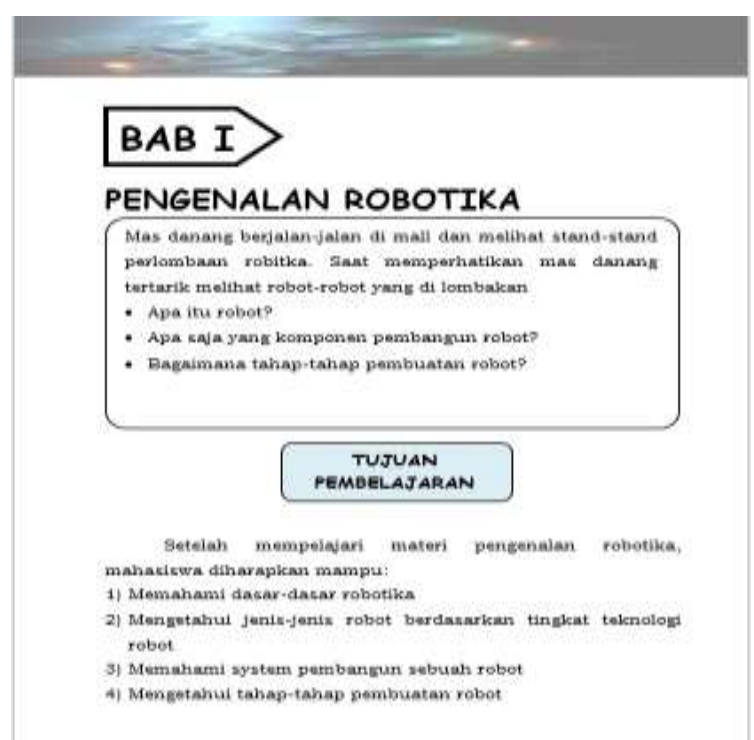

Gambar 6. Gambar Tujuan Pembelajaran Serta Pendahuluan

5. Desain warna layout pada halaman materi

Materi pada modul ini adalah materi robotika pada mata kuliah Elektronika Dasar 2 yang diadopsi dari berbagai sumber sebagai referensi. Untuk komposisi warna gambar dan layout disesuaikan dengan warna dominan pada modul ini yaitu biru dan orange. Adapun contoh tampilan materi pada subbab 1 dapat dilihat pada gambar di bawah ini.

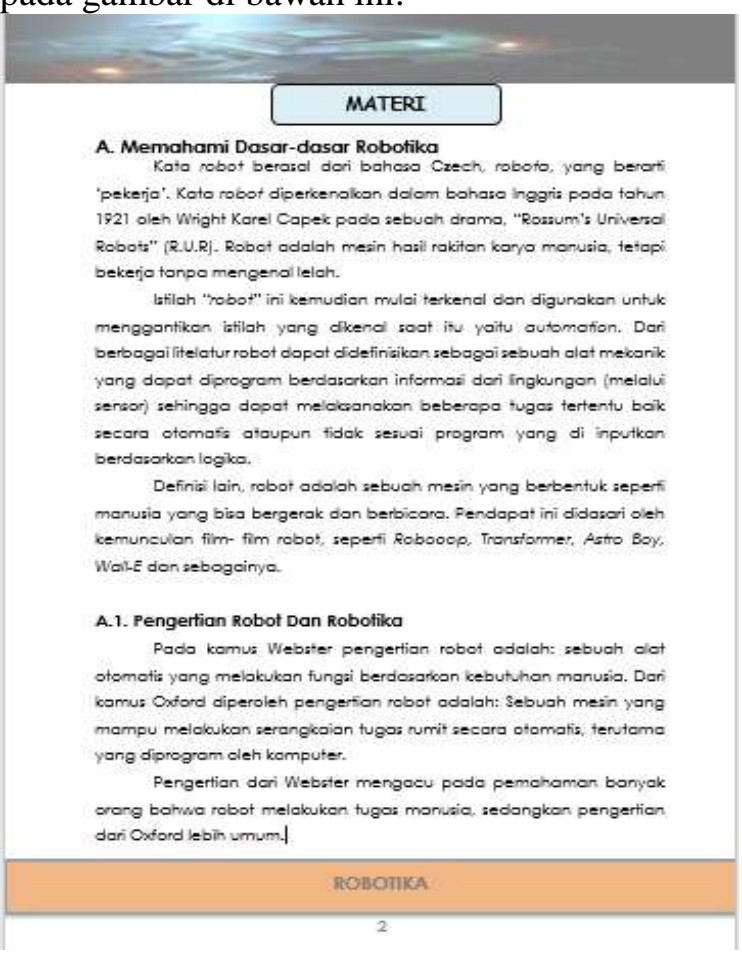

Gambar 7. Gambar Halaman Layout Materi 
6. Membuat rangkuman

Rangkuman didalam modul dibuat menjawab tujuan pembelajaran yang telah disampaikan di awal modul. Adapun desain dari rangkuman pada modul ini bisa dilihat pada gambar di bawah ini:

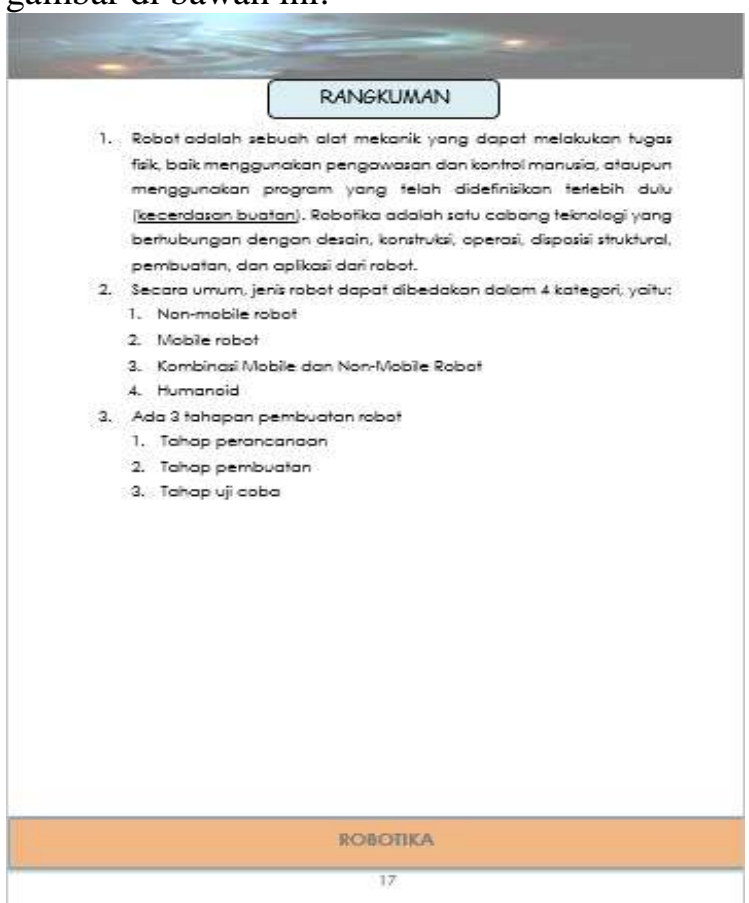

Gambar 8. Gambar Halaman Rangkuman

\section{Membuat Soal Evaluasi}

Di dalam modul ini terdapat soal evaluasi yang bertujuan untuk mengasah kemampuan mahasiswa setelah mempelajari isi dari modul. Soal evaluasi diadopsi dari berbagai sumber dan disesuaikan dengan RPS yang ada Adapun soal evaluasi yang telah dibuat oleh peneliti dapat dilihat pada gambar di bawah ini:

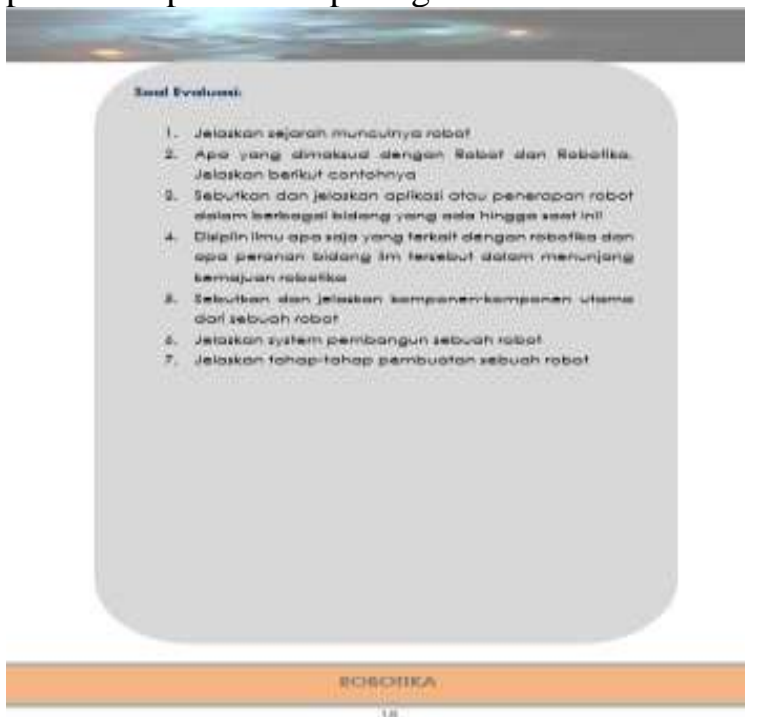

Gambar 9. Gambar Halaman Evaluasi

\section{Melakukan Revisi Formatif}

Setelah tahap desain selesai dibuat, selanjutnya adalah melakukan revisi formatif. Tujuan dilakukannya revisi formatif adalah untuk merevisi produk yangterkait dengan pembelajaran dan proses sebelum dilakukannya tahap implementasi. Selanjutnya peninjauan dilakukan oleh validator ahli materi dan validator ahli media untuk memperbaiki kesalahan yang ada pada modul yang telah dibuat. Lembar penilaian yang akan diberikan oleh validator ahli materi dan validator ahli media untuk setiap komponen berupa angka dan saran kualitatif. Kemudian, setelah lembar penilaian selesai dibuat oleh peneliti dan telah divalidasi oleh dosen pembimbing, modul dan lembar penilaian diserahkan kepada masingmasing validator ahli untuk diberikan saran dan perbaikan.

1. Validasi Ahli Materi

Dilakukan 4 kali validasi ahli materi dimana dengan hasil sebagai berturut-turut sebagai berikut $61,70,77,84$. Berdasarkan hasil analisis di atas, diketahui bahwa skor 84 termasuk ke dalam kategori baik. Dari hasil validasi keempat tidak ada saran perbaikan yang diberikan oleh validator materi untuk perbaikan materi pada modul. Secara keseluruhan modulr obotika untuk mata kuliah Elektronika Dasar 2 sudah baik dan layak diujicobakan. Hasil validasi secara keseluruhan, dapat diambil kesimpulan bahwa hasil validasi yang pertama dengan hasil validasi yang kedua memiliki selisih poin 9 dengan kategori "Cukup baik" dan hasil validasi yang kedua dengan hasil validasi yang ketiga memiliki selisih poin 7 dengan kategori "cukupt baik" dan hasil validasi ketiga dan keempat memiliki selisih poin 7 dengan kategori "baik". Hasil validasi yang pertama sudah mendapatkan nilai dengan kategori cukup baik, namun tetap dilakukan validasi yang kedua dan ketiga karena masih ditemukannya kesalahan dalam penyajian materi pada modul Robotika. Oleh sebab itu, validator masih memberikan saran perbaikan sampai modul layak digunakan.

2. Evaluasi Ahli Media

Dilakukan 3 kali validasi ahli media dimana dengan hasil sebagai berturut-turut sebagai berikut 78,98,109 Berdasarkan hasil analisis di atas, diketahui bahwa skor 109 termasuk ke dalam kategori amat baik. Dari hasil validasi ketiga tidak ada saran perbaikan yang diberikan 
oleh validator media untuk perbaikan materi pada modul robotika. Secara keseluruhan modul robotika untuk mata kuliah Elektronika Dasar 2 sudah baik dan layak diujicobakan. Hasil validasi secara keseluruhan, dapat diambil kesimpulan bahwa hasil validasi yang pertama dengan hasil validasi yang kedua memiliki selisih poin 20 dengan kategori "cukup baik" dan hasil validasi yang kedua dengan hasil validasi ketiga memiliki seleisih poin 11 dengan kategori "baik" dan hasil validasi ketiga dengan kategori "sangat baik". Hasil validasi yang pertama sudah mendapatkan nilai dengan kategori cukup baik, namun tetap dilakukan validasi yang kedua karena masih ditemukannya kesalahan dalam mendesain modul robotika. Oleh sebab itu, validator masih memberikan saran perbaikan sampai modul layak digunakan.

\section{Evaluasi(Evaluate)}

Tahapan umum yang dilakukan pada tahap evaluasi adalah:

a. Menentukan kriteria evaluasi

Menurut Branch (2009) tujuan dari tahap ini adalah untuk mengidentifikasi persepsi, pembelajaran dan kinerja sebagai tiga tingkat utama evaluasi terkait dengan desain instruksional. Berdasarkan tujuan penelitian yang dilakukan peneliti yaitu melihat persepsi mahasiswa atas modul yang telah dibuat, maka tingkat evaluasi yang dilakukan peneliti hanyalah tingkat 1 .

b. Memilih alat evaluasi

Dalam tahap ini peneliti memilih instrumen pengukuran yang akan digunakan untuk mengukur persepsi terhadap modul yang telah dikembangkan. Salah satu instrumen yang paling sering digunakan adalah angket (questionnaire), maka pada penelitian ini peneliti mengadopsi dari penelitian yang telah dilakukan oleh Olan Priambogo (2018), dengan penyesuaian yang mana hasil penelitiannya diperoleh koefisien korelasi sebesar r11=0.829 Hasil tersebut menunjukkan bahwa angket yang digunakan memiliki reliabilitas yang sangat tinggi sehingga bisa dipercaya dan bisa digunakan untuk mengambil data yang diinginkan yaitu data persepsi mahasiswa terhadap modul yang telah dikembangkan.

c. Melakukan Evaluasi

Tahap evaluasi dilakukan dengan cara mengumpulkan data persepsi mahasiswa Pengembangan Modul Mata Kuliah .... (Nehru, dkk) hal:1-16 terhadap modul robotika telah dikembangkan. Tahap pengumpulan data persepsi mahasiswa ini merupakan langkah terakhir pada penelitian pengembangan. Proses pengumpulan data persepsi mahasiswa menggunakan angket yang dikembangkan untuk melihat persepsi mahasiswa. Ujicoba modul ini melibatkan 21 mahasiswa sebagai subjek ujicoba dengan diperoleh skor 1280 .

Menurut Daryanto (2013) tantang karakteristik modul antara lain:

\section{Self Instructional}

Self Instructional yaitu melalui modul seseorang atau peserta didik mampu belajar mandiri, tidak tergantung pada pihak lain.

2. Self Contained

Self Contained yaitu seluruh materi pembelajaran dari suatu unit kompetensi atau sub kompetensi yang dipelajari terdapat di dalam satu modul secara utuh. Tujuan dari konsep ini adalah memberikan kesempatan peserta didik mempelajari materi pembelajaran yang tuntas.

\section{Stand Alone}

Stand Alone yaitu modul yang dikembangkan tidak tergantung pada media lain dalam mempelajari dan mengerjakan tugas yang ada dalam modul, peserta didik tidak tergantung pada media lain selain modul yang digunakan.

\section{Adative}

Adaptive artinya modul dapat menyesuaikan terhadap perkembangan ilmu pengetahuan dan teknologi, serta fleksibel. Modul yang adaptive adalah jika isi materi pembelajaran dapat digunakan sampai dengan kurun waktu tertentu. 5. User Friendly

User friendly artinya modul yang dikembangkan bersahabat dengan pemakainya. Setiap instruksi dan paparan informasi yang ada dalam modul bersifat membantu dan bersahabat dengan pemakainya, termasuk kemudahan peserta didik dalam merespon, mengakses sesuai dengan keinginan. Penggunaan bahasa yang sederhana, mudah dimengerti serta menggunakan istilah yang umum digunakan.

Dimana pada poin pertama dijelaskan bahwa modul harus Self Instructional atau modul harus mampu digunakan oleh peserta didik untuk belajar mandiri tanpa tergantung oleh pihak lain.

Dari poin kedua menurut Darwanto menyatakan bahwa modul memiliki karkateristik Self Contained yaitu seluruh 
materi pembelajaran dari suatu unit kompetensi atau sub kompetensi yang dipelajari terdapat di dalam satu modul secara utuh. Tujuan dari konsep ini adalah memberikan kesempatan peserta didik mempelajari materi pembelajaran yang tuntas sehingga modul dapat meningkatkan pengetahuan.

Penggunaan bahan ajar modul memiliki potensi untuk meningkatkan kemandirian belajar siswa, karena dengan menggunakan bahan ajar modul siswa dapat belajar secara mandiri, hal ini juga sesuai dengan penelitian yang dilakukan oleh Wijayanti (2014) menyatakan bahwa pembelajaran menggunakan modul dapat meningkatkan keterampilan berpikir ilmiah dengan efektif, serta penelitian yang dilakukan oleh Tumojo (2013) menyimpulkan bahwa dengan pembelajaran menggunakan modul memiliki keuntungan yaitu dapat menciptakan situasi pembelajaran yang mampu membawa siswa terlibat dalam kegiatan mengamati, membuat dugaan, dan membuat kesimpulan pada saat proses pembelajaran berlangsung.

Hal ini selaras dengan yang disimpulkan Saputra (2014) bahwa pembelajaran dengan menggunakan modul siswa dapat: 1) terlibat aktif karena pembelajarannya berpusat pada siswa, 2) mengeksplorasi secara terbuka pemikiran dalam memecahkan masalah, 3) mengkomunikasikan dalam bentuk tulisan, 4) menemukan dan menuliskan informasi dari masalah yang disajikan, 5) lebih senang belajar, 6) menemukan tantangan. Sedangkan menurut Nasution (2000) menjabarkan kelebihan menggunakan modul yaitu: 1) pembelajaran menggunakan modul memungkinkan siswa untuk menguasai bahan pelajaran secara tuntas sehingga siswa lebih mantap untuk menghadapi pelajaran baru, dan 2) modul memuat langkah-langkah belajar yang teratur sehingga memungkinkan tumbuhnya motivasi belajar siswa yang lebih kuat.

Dari beberapa penelitian yang telah dilakukan, dapat disimpulkan bahwa pembelajaran dengan menggunakan modul lebih aktif karena pembelajarannya berpusat kepada siswa dan dapat belajar secara mandiri sehingga pembelajaran menggunkan modul dapat meningkatkan kemandirian dan pengetahuan peserta didik.0

Layak atau tidaknya modul dapat diketahui setelah melakukan validasi ahli materi, validasi ahli media dan selanjutnya diujicobakan. Untuk validasi ahli materi dilakukan sebanyak 4 kali, yang mana hasil validasi tahap 1 diperoleh skor sebesar 61 dan termasuk dalam kriteria cukup baik. Validator memberikan saran dan perbaikan guna menghasilkan modul yang maksimal. Setelah dilakukan perbaikan, maka dilakukan validasi tahap 2, yang mana hasil validasi tahap 2 diperoleh skor 70 dalam kategori cukup baik, dengan saran dari validator setelah melakukan perbaikan maka dilakukan validasi tahap 3, yang mana hasil validasi tahap 3 diperoloh skor 77 dan masi dalam kategori cukup baik, pada tahap ini kelengkapan materi telah tercapai, setalah melakukan perbaikan maka dilakukan validasi tahap 4, yang mana pada validasi tahap 4 diperoleh skor 84 dengan kategori baik.

Setelah tahap validasi ahli materi selesai, selanjutnya yaitu validasi ahli media. Validasi ahli media dilakukan sebanyak 3 kali, yang mana hasil validasi tahap 1 diperoleh hasil skor sebesar 78 dan termasuk dalam kategori cukup baik, setelah melakukan perbaikan maka dilakukan validasi tahap 2 dimana diperoleh skor hasil sebesar 98 yang dimana termasuk dalam kategori baik, meskipu sudah dalam kategori baik validator memberikan saran agar menghasilkan modul yang maksimal. Setelah dilakukan perbaikan maka dilakukan validasi tahap 3 dan diperoleh skor sebesar 109 dengan kategori amat baik. Sehingga dapat disimpulkan modul dapat digunakan tanpa revisi.

Produk modul terdiri dari 4 bab dimana setiap bab terdapat materi bahasan dan evaluasi soal. Bab I Modul menjeleskan tentang penegenalan robotika dimana penjelasan materi bercakup diantara memahami dasar-dasar robotika, sejarah robotiuka, jenis-jenis robotika dan hal-hal mendasar lainya. Pada bab selanjutnya menjelaskan tentang piranti pengendali, yang mencakup materi tentang kontrol secara otomatis terprogram dan control secara manual. Di bab III menjelaskan tentang mikrokontroler dimulai dari hal-hal dasar tentang mikrokontroler, penjelasan tentang ATmega16 dan ATmega 8535, lalu penjelasan tentang Bahasa $\mathrm{C}$ dan diakhiri dengan pembuatan program sederhana tentang Led kelip. Bab terakhir atau bab IV menjelaskan 
tentang akuarot robot meliputi penjelasan tentang akuator, jenis jenis akuator, system control dan pada bagian terakhir perancangan robot line follower. Modul didominasi oleh warna orange serta biru. Lalu total terdapat 122 halaman pada modul. total terdapat 122 halaman pada modul. Modul dilengkapi engan gambar-gambar agar dalam melaksanakan project mandiri mahasiswa lwbih dapat memahami proses yang dilakukan. Untuk pengecekan plagiasi digunakan software Turnitin dengan hasil akhir hanya sebesar $18 \%$. Dimana pada awalnya 28\% yang kemudian direvisi secara berkala Bersama validator materi.

Modul yang dikembangkan memiki kelebihan dan kekurangan: Kelebihan dari modul materi robotika untuk mahasiswa Pendidikan Fisika yaitu:

1. Modul ini menyajikan materi robotika yang lebih ringkas dan mudah dipahami dari sumber belajar lain yang digunakan dalam pembelajaran Eektronika Dasar II

2. Modul didesain semenarik mungkin agar menarik minat pembaca, mulai dari warna desain, bentuk font, gambar yang lebih menarik dibandingkan sumber belajar yang ada.

3. Didalam modul terdapat project-project yang dapat dipelajari untuk memudahkan mahasiswa dalam mempelajari materi mikrokontroler

4. Modol dilengkapi dengan CD agar mahasiswa tidak repot mencari desain gambar pcb ataupun sensor serta tidak repot mengetik ulang program yang di buat.

Adapun kekurangan yang terdapat didalam modul ini yaitu:

1. Gambar didalam modul sudah diberikan dengan jelas. Namun masi banyak kekurangan dikarenakan gambar tidak dijelaskan fungsi nya secara mendetail. Seperti gambar arsitektur atmega 16 yang tidak dijelaskan secara rinci.

2. Modul tersebut juga belum bersifat interaktif terhadap pengguna. Maksudnya adalah hubungan timbal balik antara mahasiswa dengan dosen, mahasiswa satu dengan mahasiswa lainnya atau mahasiswa dengan modul itu sendiri.

3. Contoh project masi terlalu sedikit yang diberikan, hanya ada 2 contoh projek yanf diberikan didalam modul yaitu projek pembutan running LED dan Pembutan robot Line Follower.

\section{Simpulan dan Saran}

Simpulan

Berdasarkan proses pengembangan ADDIE (Analysis, Design, Development, Implementation, and Evaluation), maka disusunlah Modul Materi Mata Kuliah Elektronika Dasar II Materi Robotika. Hasil penelitian ini berupa modul cetak yang berisi materi tentang dasar robotika, piranti pengendali, mikrokontroler dan aktuator. Modul dilengkapi dengan kegiatan belajar mandiri merancang projek sederhana. Hasil validasi ahli materi diperoleh skor 84 dengan kategori baik dan hasil validasi ahli media diperoleh skor 109 dengan kategori sangat baik. Hasil persepsi mahasiswa diperoleh bahwa ratarata untuk aspek desain pembelajaran sebesar 66.75 untuk aspek materi dalam modul sebesar 66,3 , untuk aspek keterbacaan modul sebesar 67,6 , dan untuk aspek visualisai modul sebesar 67,5. Modul robotika yang telah dikembangkan memenuhi standar media dan bahan ajar yang sangat baik.

Saran

Peneliti selanjutnya diharapkan dapat menyempurnakan modul mata kuliah elektronika dasar II materi robotika dengan menjelaskan fungsi dari gambar-gambar yang dimuat didalam modul agar lebih mudah dipahami oleh mahasiswa dan menambah projek. Modul ini diharapkan dilakukan uji coba untuk mengetahui pengaruh penggunan modul terhadap kemandirian dan pengetahuan mahasiswa.

\section{Daftar Pustaka}

Akdon, dan Riduwan,2013. Rumus dan Data Dalam Analisis Statistika. Bandung:Alfabeta.

Arkin, R.C. (1998) Behavior-based Robotics. Cambridge, England: The MIT Press.

Branch, R. M. (2009). Instructional design: The ADDIE approach (Vol. 722): Springer Science \& Business Media.

Claes, Daniel, Karl Tuyls (2018) Multi robot collision avoidance in a shared workspace. Department of Computer Sciences, University of Liverpool, 
Ashton Building, Ashton Street, Liverpool.

Coste-Maniere, E. and Simmons, R. (2000). Architecture, the Backbone of Robotic Systems. Proceeding of the 2000 IEEE International Conference on Robotics and Automation, San Francisco, CA.

Daryanto. (2013). Strategi dan tahapan mengajar (bekal keterampilan dasar bagi guru) Bandung: CV Yrama Widya.

Ha, Changsu et al. Teleoperation of a platoon of distributed wheeled mobile robots with predictive display. Department Mechanical and Aerospace Engineering and IAMD of Seoul National University, Seoul.

Mataric, M.M. (1997). Behavior-Based Control: Examples from Navigation, Learning, and Group Behavior. Journal on Experimental and Theoretical Artificial Intelligence Special Issue on Software Architectures for Physical Agents.

Mataric, M.M. (1998) Behavior-based Robotics as a Tool for Synthesis of Artificial Behavior and Analysis of Natural Behavior. Trends in Cognitive Science. Vol. 2. No. 3, March 1998.

Nasution, S. 2000. Berbagai Pendekatan dalam Proses Belajar Mengajar. Jakarta: Bumi Aksara.

Nehmzow, U. (2001). Mobile Robotics: Research, Applications and Challenges,
Proceeding of Future Trends in Robotics, Institution of Mechanical Engineer, London, UK. 2001.

Saputra, J. 2014. Pengembangan Modul Kontekstual Pada Materi Segitiga Kelas VII. Tesis. Tidak diterbitkan. Malang: PPs UM.

Sugiyono. 2015. Metode Penelitian Pendidikan (Pendekatan Kuantitatif, Kualitatif dan $R \& D)$. Penerbit CV. Alfabeta: Bandung.

Sugiyono. (2013). Metode Penelitian Kuantitatif, Kualitatif dan R \& D. Bandung: Alfabeta.

Supriyanto, Raden dkk. 2010. Buku Robotika. Tanggerang: Universitas Gunnadarma.

Tumojo, B. 2013. Pengembangan Modul Pembelajaran Bercirikan Penemuan (Discovery) untuk membangun Kemampuan Peserta Didik dal Memahami Materi Trigonometri. Tesis. Tidak diterbitkan. Malang: PPs UM.

Wijayanti, A. 2014. Pengembangan Autentic Assesment Berbasis Proyek Dengan Pendekatan Saintifik Untuk Meningkatkan Keterampilan Berpikir Ilmiah Mahasiswa. 